\title{
Hepatitis B Reactivation with Novel Agents in Non-Hodgkin's Lymphoma and Prevention Strategies
}

\author{
Oluwatobi O. Ozoya ${ }^{1}$, Lubomir Sokol ${ }^{2}$ and Samir Dalia*3 \\ ${ }^{1}$ Emergency and Trauma Center, Tampa General Hospital, Tampa, FL, USA; ${ }^{2}$ Department of Hematological Malignancies, \\ H. Lee Moffitt Cancer Center, Tampa, FL, USA; ${ }^{3}$ Oncology and Hematology, Mercy Clinic Joplin, Joplin, MO, USA
}

\begin{abstract}
Hepatitis B virus (HBV) infection remains an endemic disease in most parts of the world despite available prophylactic vaccines. Non-Hodgkin's lymphoma is the most common hematological malignancy, and certain patients undergoing therapy are at increased risk of HBV reactivation. Rituximab, a monoclonal antibody, is well studied in HBV reactivation, but newer agents have been implicated as well. Here, we review novel agents suspected in HBV reactivation and effective strategies to prevent HBV reactivation. Fifteen years of literature were reviewed in order to better understand the reactivation rates of hepatitis B in patients with non-Hodgkin's lymphoma. Anti-CD20 antibodies continue to be the main medications that can lead to HBV reactivation, and HBV reactivation rates have decreased with increased awareness. HBV reactivation is uncommon when using other novel agents. Entecavir and lamivudine remain the agents of choice to prevent HBV reactivation in high risk patients. In conclusion, the immunosuppressive effect of NHL and its therapy provide a pathway for HBV reactivation, especially in patients treated with anti-CD2O antibody. Since many HBV positive patients are often excluded from clinical trials of novel agents in $\mathrm{NHL}$, more aggressive post-market surveillance of new agents, welldesigned best practice advisories, and timely case reports are needed to reduce the incidence of HBV reactivation. Lastly, large prospective investigations coupled with well-utilized best practice advisories need to be conducted to understand the impact of more potent novel NHL therapy on HBV reactivation. (C) 2016 The Second Affiliated Hospital of Chongqing Medical University. Published by XIA \& HE Publishing Inc. All rights reserved.
\end{abstract}

Keywords: Hepatitis B virus; HBV reactivation; Non-Hodgkin's lymphoma; Rituximab; Anti-CD20 antibody; Best practice advisories.

Abbreviations: AASLD, American Association for the Study of Liver Diseases; ACIP, Advisory Committee on Immunization Practices; AGA, American Gastroenterological Association; ALT, alanine aminotransferase; anti-HBc, HBV core antibody; APASL, Asian-Pacific Association for the Study of the Liver; ASCO, American Society of Clinical Oncology; BTK, Bruton's kinase; CDC, Centers for Disease Control and Prevention; $\mathrm{CI}$, confidence interval; $\mathrm{CLL}$, chronic lymphocytic leukemia; CPOE, computerized physician order entry; DLBCL, diffuse large B-cell lymphoma; EASL, European Association for the Study of Liver Disease; FDA, Food and Drug Administration; HBsAg, hepatitis B surface antigen; HBV, hepatitis B virus; HIV, human immunodeficiency virus; HR, hazard ratio; NCCN, National Compre-

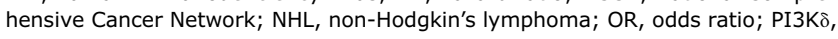
phosphatidylinositol 3-kinase delta inhibitors; RR, risk ratio.

Received: 13 February 2016; Revised: 25 April 2016; Accepted: 26 April 2016 DOI: $10.14218 / \mathrm{JCTH} .2016 .00005$

*Correspondence to: Samir Dalia, Oncology and Hematology, Mercy Clinic Joplin, 100 Mercy Way, Joplin, MO 64804, USA. Tel: +1-417-782-7722, Fax: +1-417-556-3063, E-mail: sdalia@gmail.com or Samir.dalia@mercy.net

\section{Introduction}

Hepatitis B virus (HBV) is a DNA virus that resides exclusively in human reservoirs and is transmitted through body fluids. The infective form remains prevalent globally despite available prophylactic immunization. Endemicity is present in Asia, Africa, the Middle East, parts of Eastern Europe, and South America, and up to 400 million people are chronically infected. ${ }^{1}$ Although the United States is non-endemic for $\mathrm{HBV}$, up to 1 million people have chronic HBV, and the risk of acute infection persists. Estimated age-adjusted prevalence in the US is $4.7 \%$ for core antibody (anti-HBc) and $0.27 \%$ for surface antigen ( $\mathrm{HBsAg}$ ). ${ }^{2}$ In addition, $\mathrm{HBsAg}$ prevalence rate is thought to be $0.75 \%$ in those who receive immunosuppressive therapy and is highest among those with co-infection of the human immunodeficiency virus (HIV). ${ }^{3}$ Vaccination efforts have contributed to the decrease in anti$\mathrm{HBC}$ prevalence rate from $1.9 \%$ in 1999 to $0.6 \%$ in 2006 for those aged 6 to 19 years. Among adults older than 50 years of age, the prevalence rate decreased marginally from $7.7 \%$ in 1999 to $7.2 \%$ in $2006 .^{2}$ Moreover, HBV has been implicated in the incidence of non-Hodgkin's lymphoma $(\mathrm{NHL}),{ }^{4-7}$ which increases with advancing age for all race and gender subgroups. ${ }^{8,9}$

$\mathrm{NHL}$ is one of the most prevalent hematological malignancies globally and contributed to over 190,000 deaths in 2008. ${ }^{10} \mathrm{NHL}$ is also common in the US, where almost 20,000 patients will die from this disease each year, despite available chemotherapy. ${ }^{11}$ Cytotoxic chemotherapy, which is highly immunosuppressive, has been linked to reactivation of HBV infection in seropositive and seronegative cases (undetectable anti-HBc and anti-HB surface antigens). ${ }^{12-18}$ The mechanisms underlying HBV reactivation in NHL therapy include the active roles of acquired viral genomic mutations, chronic viral infection, immunosuppression, and exaggerated immune response following cessation of chemotherapy. $7,19-21$ The definition of HBV reactivation can vary, but it must include a 10 -fold rise in HBV DNA in a patient with past or latent HBV infection and/or levels > 10,000 copies/mL (4 log copies $/ \mathrm{mL}$ ). ${ }^{7,22,23}$ A serum transaminase level three times the upper limit of normal or alanine aminotransferase (ALT) over $100 \mathrm{IU} / \mathrm{L}^{7,19,24}$ in a patient with known HBV seropositivity may also be considered HBV reactivation. ${ }^{22} \mathrm{HBV}$ reactivation is important in patients treated for $\mathrm{NHL}$, as it increases the likelihood of stopping therapy, may lead to liver failure, and can increase the risk of mortality. ${ }^{24-26}$

Chemo-immunotherapy induced HBV reactivation can be preventable if detected early. A vast majority of the NHL literature on $\mathrm{HBV}$ reactivation has focused on rituximab. With 
the advent of newer immunotherapy agents, less is understood about the incidence and prevention of HBV reactivation. This review aims to summarize recent data on the reactivation of HBV with novel agents in NHL therapy and effective methods to prevent HBV reactivation in these patients.

\section{Review Criteria}

Relevant articles for this review were identified by searching PubMed, Embase, Ovid Medline, and Scopus using the following terms, alone and in combination: "Hepatitis B reactivation", "novel agents", "Non-Hodgkin's lymphoma", "immunosuppression", "immunocompromised host", "immunosuppressive agents", "hepatitis B", "hepatitis B virus", "HBV", "reactivation", "management" and "prevention". Full text articles of all selected studies were retrieved, and if a paper was selected for inclusion, the bibliographic references were scrutinized to identify additional relevant studies. The period of the search was restricted to a 15 year period to limit the search to novel agents in the treatment of NHL (2000-2015).

\section{Hepatitis B reactivation in NHL therapy}

Hepatitis B reactivation in susceptible individuals has been linked with chemotherapy through amplification of viral replication and immune function recovery following chemotherapy induced-immunosuppression. ${ }^{20,21,26,27}$ Reactivation is also attributable to profound immunosuppression induced by lymphocytotoxic monoclonal antibodies 27,28 . In the largest study $(10,729$ patients) on HBV reactivation in patients receiving chemotherapy, predictors included male gender, race (Asian, Black), rituximab use, and presence of hepatitis $B$ risk factors. The risk of reactivation was high in individuals with anti-HBc or anti-HBs and even higher in those with seropositive HBsAg. 28

The severity of chemotherapy-induced HBV reactivation in $\mathrm{NHL}$ has been categorized as low risk with azathioprine and methotrexate moderate risk with commonly used cytotoxic chemotherapy, such as CHOP (cyclophosphamide, doxorubicin, vincristine, and prednisone), high-dose corticosteroids (prednisolone $>20 \mathrm{mg}$ ), and fludarabine. Patients who received antiCD20 monoclonal antibodies, such as rituximab, were at the highest risk for HBV reactivation. ${ }^{29,30}$

Among the monoclonal anti-CD20 antibodies, rituximabassociated HBV reactivation has been the most commonly reported event. $7,20,26$ Two meta-analyses have demonstrated more than a five-fold increased risk of HBV reactivation with rituximab chemotherapy based on HBcAb serum level (risk ratio (RR) of 5.52, 95\% confidence interval (CI) 2.05-14.85, $p<0.001)^{12}$ and odds ratio (OR) of 5.73, 95\% CI 2.01-16.33; $Z=3.33, p<0.001 .^{13}$ The first published meta-analysis reported a $55 \%$ liver failure rate, ${ }^{13}$ while another reported that $43 \%$ of participants developed adverse hepatic-related events. ${ }^{7}$ In addition, early studies on HBV reactivation rates from rituximab combined chemotherapy reported rates up to $56 \%$, especially in HBV endemic regions. ${ }^{22,31,32}$ However, more recent studies have reported lower reactivation rates $(<2.7 \%)$ and lower mortality rates, ${ }^{14,15,33,34}$ even in high prevalent regions. This discrepancy may be explained by improved defined criteria and awareness of HBV reactivation. ${ }^{14,35}$ In addition, reactivation rates may be reduced due to early diagnosis and increased knowledge of the management of chronic hepatitis $B$ and the associated HBV reactivation in oncologic therapy. ${ }^{30,36}$
In addition to rituximab, ofatumumab was included in the Food and Drug Administration (FDA) reactivation warning 4 years after its approval in 2009.24,37 A search of the FDA Adverse Event Reporting System database yielded 32 cases of rituximab-associated HBV reactivation and one case associated with ofatumumab (http://www.fda.gov/Drugs/DrugSafety/ucm366406.htm). Data in support of ofatumumab in HBV reactivation is still sparse, and a recent European Phase IV trial in advanced chronic lymphocytic leukemia (CLL) categorically reported no case of HBV reactivation in patients treated with ofatumumab. ${ }^{38}$ Obinutuzumab, recently approved by the FDA for CLL in 2013, has a black box warning for HBV reactivation. However, no published data exist to support this report. ${ }^{39,40} \mathrm{~A}$ search from the FDA Adverse Event Reporting System database did not yield any data to support this report (http:// www.fda.gov/Drugs/DrugSafety/PostmarketDrugSafety InformationforPatientsandProviders/ucm111085.htm\#O; http://www.fda.gov/drugs/informationondrugs/approved drugs/ucm 373263. htm). A Japanese Phase I study of obinutuzumab in refractory B-cell NHL excluded patients with seropositive HBV status, ${ }^{41}$ thereby precluding the usefulness of identifying adverse events through clinical trials. ${ }^{42}$

Although there is no FDA warning yet, few case reports of HBV reactivation have been reported with other monoclonal agents used to treat NHL. Alemtuzumab (anti-CD52) therapy, mainly used in CLL, increased HBV DNA level to 7.3 log copies/mL in one patient, ${ }^{43}$ while mogamulizumab in adult T-cell leukemialymphoma increased HBV DNA to a range of 2.1 to $9.1 \mathrm{log}$ copies/mL during therapy for four different patients. ${ }^{44,45}$ Other novel agents, such as the small molecule inhibitors [Bruton's kinase (BTK) inhibitors and phosphatidylinositol 3-kinase delta inhibitors (PI3K $\delta$ )], have been linked to the occurrence of autoimmune hepatitis, but it is unclear if HBV reactivation can occur. ${ }^{20,46,47}$ Idelalisib, a potent, small-molecule inhibitor

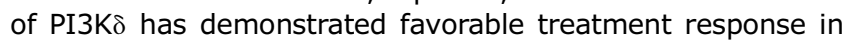
patients with indolent NHL who are refractory to rituximab and other previous chemotherapy. ${ }^{48,49}$ Asymptomatic elevated transaminase levels was reported in $47 \%-48 \%$ of such patients, and $13 \%-25 \%$ had grade 3 elevations, although most cases resolved following dose reduction. ${ }^{48,49}$ It is unclear if these are negligible laboratory abnormalities or an indication that patients with HBV risk factors treated with PI3K $\delta$ inhibitors may develop overt HBV reactivation. ${ }^{50,51}$ Clinical trials of these agents in combination with rituximab are underway, and the outlook in regard to HBV reactivation is guarded until more post-market surveillance data emerge. ${ }^{42,52}$ Table 1 summarizes confirmed and suspected novel agents with HBV reactivation sequela.

\section{Prevention Strategies}

\section{HBV screening, best practice advisories, and HBV vaccination}

Screening for both HBV reactivation and HBV risk factors is the first step in preventing reactivation in patients undergoing therapy for $\mathrm{NHL}{ }^{28,30,53}$ Organizational policies on screening have significantly increased screening rates over the last 6 years from $20 \%$ to $90 \%$ at large oncology centers in the US. ${ }^{24,28}$ Policies on screening modalities are also gradually shifting from a targeted approach to a universal approach.

A targeted screening approach for patients undergoing chemo-immunotherapy on the basis of HBV risk status is limited since chronic hepatitis may be asymptomatic, and 
Ozoya O.O. et al: Hepatitis B reactivation with novel agents

Table 1. Novel agents and HBV reactivation status

\begin{tabular}{|c|c|c|c|c|c|}
\hline agent & Target & Indication & $\begin{array}{l}\text { HBV } \\
\text { reactivation } \\
\text { Status }\end{array}$ & $\begin{array}{l}\text { Data } \\
\text { source }\end{array}$ & References \\
\hline \multicolumn{6}{|l|}{$\begin{array}{l}\text { Monoclonal } \\
\text { antibodies }\end{array}$} \\
\hline Rituximab* & CD20 & $\begin{array}{l}\text { Relapsed or refractory indolent } \\
\text { lymphoma maintenance therapy in } \\
\text { B-cell NHL }\end{array}$ & $\begin{array}{l}\text { FDA boxed } \\
\text { warning }\end{array}$ & $\begin{array}{l}\text { FDA } \\
\text { AERS }\end{array}$ & $13-15,30,31,37$ \\
\hline Ofatumumab* & CD20 & Relapsed/refractory CLL & $\begin{array}{l}\text { FDA boxed } \\
\text { warning }\end{array}$ & $\begin{array}{l}\text { FDA } \\
\text { AERS }\end{array}$ & 37,38 \\
\hline Obinutumumab* & CD20 & Rituximab-refractory patients & $\begin{array}{l}\text { FDA boxed } \\
\text { warning }\end{array}$ & $\begin{array}{l}\text { FDA } \\
\text { AERS }\end{array}$ & $39-41$ \\
\hline Alemtuzumab ${ }^{\S}$ & CD52 & Refractory B-CLL & $\begin{array}{l}\text { +HBVr but no } \\
\text { FDA warning } \\
\text { yet }\end{array}$ & $\begin{array}{l}\text { Case } \\
\text { reports }\end{array}$ & 27,43 \\
\hline Mogamulizumab ${ }^{\S}$ & $\begin{array}{l}\text { CC } \\
\text { chemokine } \\
\text { receptor }\end{array}$ & $\begin{array}{l}\text { Aggressive adult T-cell leukemia- } \\
\text { lymphoma (ATL) and peripheral T-cell } \\
\text { lymphoma }\end{array}$ & $\begin{array}{l}+\mathrm{HBV} \text { but no } \\
\text { FDA warning } \\
\text { yet }\end{array}$ & $\begin{array}{l}\text { Case } \\
\text { reports }\end{array}$ & 44,45 \\
\hline \multicolumn{6}{|l|}{$\begin{array}{l}\text { Small molecule } \\
\text { inhibitors }\end{array}$} \\
\hline Ibrutinib $^{\S}$ & $\begin{array}{l}\text { BTK } \\
\text { inhibitors }\end{array}$ & Low-grade NHL & $\begin{array}{l}\text { Immune } \\
\text { hepatitis }\end{array}$ & $\begin{array}{l}\text { Clinical } \\
\text { trials }\end{array}$ & 46,47 \\
\hline Idelalisib ${ }^{\S}$ & $\begin{array}{l}\text { PI3K } \delta \\
\text { inhibitors }\end{array}$ & Relapsed/Refractory low-grade NHL & $\begin{array}{l}\text { Immune } \\
\text { hepatitis/ } \\
\text { Transaminitis }\end{array}$ & $\begin{array}{l}\text { Clinical } \\
\text { trials }\end{array}$ & 46,47 \\
\hline
\end{tabular}

${ }^{\text {a }}$ Agent - Confirmed* and suspected ${ }^{\S}$ agents with HBV reactivation sequela

Abbreviations: B-CLL, B-cell chronic lymphocytic leukemia; BTK, Bruton's kinase; FDA, Food and Drug Administration; FDA AERS, FDA Adverse Event Reporting System; $\mathrm{HBV}$, hepatitis B virus; NHL, non-Hodgkin lymphoma; PI3K $\delta$, phosphatidylinositol 3-kinase delta inhibitor.

sufficient information may not be elicited during initial patient encounters to adequately assess the risk of HBV infection. ${ }^{54,55}$ On the other hand, universal HBV screening for all patients newly diagnosed with cancer who require chemoimmunosuppressive therapy results in a more direct reduction in reactivation rates. ${ }^{24}$ In the US, hospital-enforced universal screening policies in some large cancer treatment centers provide evidence that increasing pre-therapy screening and prophylaxis for HBV can result in zero-to-minimal cases of HBV reactivation. ${ }^{28,53}$ Currently, the National Comprehensive Cancer Network (NCCN) recommends that all patients receiving an anti-CD20 antibody should be screened for HBV prior to exposure to the agent. ${ }^{56}$ Screening should be for both HBsAg and anti-HBc since HBV DNA undetected in serum can persist in tissues ${ }^{11,56,57}$ and the antigen may be absent in indolent cases of HBV. ${ }^{58}$ Patients who are found to be positive for either should be considered for HBV prophylaxis prior to chemo-immunosuppressive therapy.

According to clinical opinion in the oncologic literature, there is clear consensus on adopting screening to identify patients who are at high risk of HBV and also candidates for anti-CD20 monoclonal antibody. There are differences in opinion regarding the necessity to screen all patients who will receive chemotherapy irrespective of HBV risk status. Guidelines from the American Gastroenterological Association (AGA), ${ }^{26}$ the European Association for the Study of Liver Disease (EASL), ${ }^{59}$ the American Society of Clinical Oncology (ASCO), ${ }^{53}$ and the Asian-Pacific Association for the Study of the Liver (APASL) ${ }^{60}$ recommend that low and high risk patients receiving chemotherapy or immunotherapy should be considered for testing and prophylaxis. On the other hand, the $\mathrm{NCCN}^{57}$ and the American Association for the Study of Liver Diseases (AASLD) ${ }^{61}$ suggested excluding from screening, patients with low risk of HBV and candidates for cancer therapy associated with low risk of reactivation, because supporting evidence was insufficient. A tenable explanation for the disparity in screening approach may be consideration given to patients from regions with high HBV prevalence. At this time, clinicians should determine if screening for HBV is needed in each individual patient receiving chemotherapy. In the future, we hope that better data are available to help allocate resources for patients in need of HBV screening prior to chemotherapy. ${ }^{53}$

Improved coordination of primary care and specialist healthcare professional services is required to screen promptly all patients at risk of $\mathrm{HBV}$ infection irrespective of negative cancer status. Screening prescription by healthcare professionals to patients, prior to immunosuppressive therapy still needs to be enhanced. ${ }^{54,55,62}$ Improved screening rates to prevent HBV reactivation can be achieved with improved data management and alert systems integrated into existing electronic medical records. ${ }^{55,63}$ Between 2012 and 2013, a cancer center study showed the role of a best practice advisory (alert system) incorporated in the computerized physician order entry (CPOE) application in increasing HBV screening rates prior to therapy. At the end of the program, the study reported an improved screening rate for patients treated with biologic agents from $<50 \%$ to $>85 \%$. ${ }^{63}$ 
Since prior HBV infection prior HBV infection is a baseline risk factor for HBV reactivation, prevention efforts need to maintain a clear distinction between identifying risk factors for HBV reactivation and for HBV infection. ${ }^{28,36}$ Notable risk factors for HBV infection include groups such as healthcare workers, injecting drug users, recipients of blood products or dialysis, household contacts of people with chronic HBV infection, incarcerated persons, people with multiple sex partners, men who have sex with men, and unvaccinated or partially vaccinated travelers to high endemic regions. ${ }^{36}$ Low and intermediate endemic countries require catch-up immunization targeted at these high risk groups. In addition, programs that mandate $\mathrm{HBV}$ vaccination for entry into schools, colleges, and work-places remain an effective strategy to reduce HBV infection in low-intermediate endemic regions. ${ }^{36}$

The Advisory Committee on Immunization Practices (ACIP) of the Centers for Disease Control (CDC) recommends universal vaccination of individuals, especially male adults, who test positive, since the risk of hepatitis $B$ remains highest in this group. ${ }^{36}$ This recommendation is important because adult males have a higher incidence of $\mathrm{NHL}$ compared to women of the same age group..$^{8,9,64}$ For children, universal vaccination at childbirth with follow-up remains appropriate for high endemic ( $>8 \%$ ) regions. On a global scale, newborns who received a birth dose of HBV vaccine increased from $27 \%$ to $38 \%$ between 2006 and 2014. Birth cohorts who received three doses in 2008 and 2014 increased from $69 \%$ to $82 \%$. Although these data indicate that HBV vaccination rates are rising, there is still room for improvement in high endemic areas. ${ }^{1,65}$ Since the last two decades, the CDC has recommended routine post-vaccination tests for anti-HBs and annual booster doses for sustained immunity among high risk groups and immunocompromised persons. ${ }^{66}$ Therefore, targeted and universal vaccination efforts should not wane, because the risk of exposure to HBV continues to persist.

\section{Reactivation prophylaxis and therapy}

HBV seropositive individuals who require chemotherapy or anti-CD20 antibody therapy should be started on antivirals in a timely manner. Globally, lamivudine has been the most utilized nucleos(t)ide analogue for the prevention of HBV reactivation during chemo-immunotherapy. ${ }^{33,67-70}$ Prognosis of patients with lamivudine following HBV reactivation remains favorable, despite few cases of viral resistance. ${ }^{71}$ Newer nucleos(t)ide are now favored in reactivation management. ${ }^{71-75}$ Newer nucleos(t)ide analogues, such as entecavir, adefovir, and tenofovir, have been used because of their lower viral resistance. ${ }^{27,57}$ In a notable study, $\mathrm{Li}$ and others compared entecavir with lamivudine as prophylaxis for hepatitis $B$ reactivation in lymphoma patients undergoing chemotherapy. The entecavir group exhibited a significantly lower rate of HBV reactivation ( $0 \%$ vs $12.4 \%, p=0.024)$ and a lower incidence of aborted chemotherapy compared to the lamivudine group (5.9 vs $20.2 \%, p=0.042$ ). ${ }^{74}$

The stage of NHL disease is a useful criterion when considering use of nucleos(t)ide analogues. Studies have shown that the efficacy of entecavir is higher than that of lamivudine, especially in advanced disease. ${ }^{72,76}$ In advanced diffuse large B-cell lymphoma (DLBCL), Huang and colleagues compared entecavir and lamivudine and demonstrated that there was a lower reactivation rate $(6.6 \%$ vs $30 \%$; difference, $23.4 \%$ [ $95 \% \mathrm{CI}, 10.2 \%$ to $36.6 \%$ ]; $p=.001$ ) and premature chemotherapy cessation ( $1.6 \%$ vs $18.3 \%$; difference, $16.7 \%$
[95\% CI, $6.4 \%$ to $27.0 \%$ ]; $p=.002$ ) with entecavir compared to lamivudine. ${ }^{72}$ Importantly, despite the lower risk of viral resistance with tenofovir, adefovir, and entecavir compared to lamivudine, ${ }^{77}$ these newer agents on rare occasions were associated with mild renal dysfunction with long-term use. ${ }^{20,78,79}$ Therefore, dosage of these agents needs to be adjusted in renal impairment, and renal function should be assessed at least every 3 months. ${ }^{57,79}$

Another study that explored steroid-free chemotherapy in the prevention of $\mathrm{HBV}$ reactivation in $\mathrm{NHL}$ reported a lower incidence and severity of reactivation when compared to steroid-containing chemotherapy. ${ }^{80}$ Despite the overall survival rate, which was higher in the steroid-containing group, a limitation of this approach may be deciding between survival following rituximab-containing therapy and the risk of HBV reactivation. Finally, more studies are needed to understand the efficacy of antivirals when both rituximab and steroids are used. ${ }^{81}$

Therapeutic intervention for HBV reactivation in aggressive lymphomas/NHL is indicated in instances such as missed HBV status and failed or interrupted prophylactic therapy. ${ }^{27,82-84}$ Failure of prophylactic lamivudine may result in withdrawal hepatitis, viral breakthrough, or mortality from liver failure. ${ }^{85,86}$ Predictors of lamivudine failure in a study include: elevated baseline HDV DNA titer ( $\geq 2,000 \mathrm{IU} / \mathrm{mL}$ ) (hazard ratio [HR], 9.94; $p=0.0063)$ and the use of rituximab (HR, 3.19; $p=0.027$ ) for viral breakthrough, while for withdrawal hepatitis, a high baseline HBV DNA titer (HR, 5.90; $p=0.007)$, liver cirrhosis (HR, 10.4; $p=0.002)$, and distant metastasis (HR, 5.14; $P=0.008$ ) were independent risk factors. ${ }^{86}$ Therapeutic interventions also depend on the presence of secondary liver failure and prognosis of the lymphoma. Newer antivirals may be used where liver failure is absent. ${ }^{27,75}$ For patients with HBV reactivation resulting in liver failure, the AGA recommends liver transplantation. ${ }^{26,75}$ Favorable outcomes were recorded in patients who underwent liver transplantation and antiviral therapy, having established prior complete remission of disease and a favorable prognosis of the lymphoma type. ${ }^{75,87}$

Based on better outcomes from recent data, recent ASCO and NCCN guidelines on HBV reactivation recommend, when possible, that patients who are HBV positive (HBsAg-positive and/or anti-HBc positive) and require chemo-immunotherapy should be placed on prophylaxis with entecavir for the duration of treatment. ${ }^{53,61}$ Other agents, including tenofovir and lamivuidine, can also be used, but there may be more resistance to lamivudine therapy. Newer antiviral medications are readily favored considering the relatively high barrier to viral resistance compared to lamivudine for both prophylactic and therapeutic purposes. The literature suggests that prophylaxis against rituximab associated HBV-reactivation should be extended up to 12 months following oncologic therapy and should be combined with HBV viral load surveillance every 3 months. ${ }^{30,53,57}$ Although NCCN warns against lamivudine as a routine prophylactic agent due to risk of viral resistance, AASLD, EASL, ASIF, and APASL recommend lamivudine as a viable prophylactic agent based on its pharmacoeconomic and safety profiles. ${ }^{59-61,88}$ Specifically, the AASLD endorses lamivudine when the planned duration of chemotherapy is less than 12 months and entecavir or tenofovir for chemotherapy lasting beyond 12 months. ${ }^{20,61,89}$ In addition, the EASL advocates for use of baseline HBV DNA $<2,000$ $\mathrm{IU} / \mathrm{mL}$ for initiating lamivudine while values $>2,000 \mathrm{IU} / \mathrm{mL}$ are indications for prescribing entecavir or tenofovir. ${ }^{59}$ In addition, the APASL and ASIF recommend lamivudine for 
Ozoya O.O. et al: Hepatitis B reactivation with novel agents

Table 2. Modalities for preventing HBV reactivation

\begin{tabular}{|c|c|c|c|}
\hline \multirow{2}{*}{$\begin{array}{l}\text { Reactivation Prevention } \\
\text { Modality }\end{array}$} & \multicolumn{2}{|l|}{ Key Characteristics } & \multirow{2}{*}{ References } \\
\hline & Indication/Advantages & Drawbacks & \\
\hline \multicolumn{4}{|l|}{$\begin{array}{l}\text { Pre-NHL therapy } \\
\text { screening }\end{array}$} \\
\hline Targeted screening & $\begin{array}{l}\text { Screen NHL patients receiving } \\
\text { anti-CD20 antibody with } \\
+ \text { HBV risk status }\end{array}$ & $\begin{array}{l}\text { Missed cases } \\
\text { (asymptomatic HBV infection) }\end{array}$ & $53,61,62$ \\
\hline Universal screening & $\begin{array}{l}\text { Screen all patients receiving } \\
\text { anti-CD20 antibody irrespective } \\
\text { of HBV risk status }\end{array}$ & $\begin{array}{l}\text { False HBV positive cases } \\
\text { Added cost to therapy }\end{array}$ & $26,59,60,63$ \\
\hline $\begin{array}{l}\text { Best Practice Advisory } \\
\text { (EHR alert system) }\end{array}$ & Increase HBV screening rates & Implementation cost & 56,64 \\
\hline \multicolumn{4}{|l|}{ HBV Vaccination } \\
\hline Catch-up vaccination & $\begin{array}{l}\text { Low NHL endemic regions } \\
\text { Reduced HBV reactivation rates }\end{array}$ & Missed cases & $36,54,66$ \\
\hline Universal vaccination & $\begin{array}{l}\text { High endemic regions } \\
\text { Reduced HBV reactivation rates }\end{array}$ & Surveillance cost & $1,36,54,66$ \\
\hline \multicolumn{4}{|l|}{ Reactivation Prophylaxis } \\
\hline Entecavir & $\begin{array}{l}\text { Agent of choice in advanced } \\
\text { disease. Least viral resistance }\end{array}$ & $\begin{array}{l}\text { Expensive Renal } \\
\text { insufficiency (rare) }\end{array}$ & $61,72,73,74,78$ \\
\hline Lamivudine & $\begin{array}{l}\text { Most used and studied } \\
\text { agent. Cheapest }\end{array}$ & $\begin{array}{l}\text { Withdrawal hepatitis } \\
\text { Lamivudine failure (Viral } \\
\text { resistance, viral breakthrough) }\end{array}$ & $\begin{array}{l}31,32,33,34,55 \\
68,71,85,89\end{array}$ \\
\hline Adefovir & Less viral resistance & $\begin{array}{l}\text { Expensive Renal } \\
\text { dysfunction (rare) } \\
\text { Hypophosphatemia (rare) }\end{array}$ & $27,76,80,81$ \\
\hline Tenofovir & Least viral resistance & $\begin{array}{l}\text { Expensive Renal } \\
\text { dysfunction (rare) } \\
\text { Hypophosphatemia (rare) }\end{array}$ & $19,27,70,71$ \\
\hline $\begin{array}{l}\text { Low dose/steroid free } \\
\text { chemo-immunotherapy }\end{array}$ & $\begin{array}{l}\text { Reduced incidence } \\
\text { of reactivation }\end{array}$ & $\begin{array}{l}\text { Potentially adverse } \\
\text { survival outcomes from } \\
\text { undertreated NHL disease }\end{array}$ & 83,84 \\
\hline \multicolumn{4}{|l|}{ Reactivation Treatment } \\
\hline Lamivudine & Most used agent globally & $\begin{array}{l}\text { Risk of acquired } \\
\text { viral resistance }\end{array}$ & $33,59,60,69,70,91$ \\
\hline $\begin{array}{l}\text { Newer antivirals } \\
\text { (Entecavir, Adefovir, } \\
\text { Tenofovir) }\end{array}$ & $\begin{array}{l}\text { Lamivudine failure. Liver } \\
\text { failure must be absent }\end{array}$ & $\begin{array}{l}\text { Depends on prognosis } \\
\text { of lymphoma type }\end{array}$ & $27,53,61,68,77$ \\
\hline Liver transplantation & $\begin{array}{l}\text { If liver failure is present } \\
\text { with HBV reactivation }\end{array}$ & $\begin{array}{l}\text { Depends on cost, } \\
\text { disease prognosis and } \\
\text { post-transplant sequelae }\end{array}$ & 26,75 \\
\hline
\end{tabular}

BPA- Best Practice Advisory is synonymous with Electronic Health Records (EHR) alert system.

treatment-naïve patients with evident or impending hepatic derangement. ${ }^{60,88}$ We urge clinicians to follow HBV seropositive patients closely while using novel agents for $\mathrm{NHL}$, to ensure that reactivation does not occur. Clinicians should also remember to screen patients for HBV who are receiving chemotherapy without rituximab, if they are at high risk for reactivation. If a patient is positive for $\mathrm{HBV}$, then prophylaxis should be initiated. The literature remains unclear at this time whether universal screening for HBV should be done in all patients receiving chemotherapy.
There are groups of patients in whom routine antiviral therapy may not be indicated. These groups include patients who do not meet the criteria for reactivation (the rise in HBV DNA $<10$-fold in patients with past or latent infection, ALT level < three times the upper limit of normal), younger patients in the immune-tolerant phase (normal ALT levels despite positive HBsAg and HBV DNA and minimal hepatic inflammation), and patients in the inactive carrier phase. In addition, patients are considered low risk with agents such as low dose corticosteroids or immunosuppressive agents (e.g., azathioprine and 6-mercaptopurine), and may be excluded 
from routine antiviral prophylaxis. Further research is needed to assess the risk in these patients. ${ }^{30,53,90}$

Lastly, critical consideration should be given to factors that may impact the potential outcomes of prophylactic and therapeutic interventions for HBV reactivation. These factors include cost of newer antivirals, liver transplant cost, medication adherence, development of mutant HBV, adverse effects of therapy, and a prolonged monitoring period. ${ }^{68,83,84,91}$ Further studies are needed to better understand these issues. Table 2 provides a summary of the modalities for preventing HBV reactivation.

\section{Conclusion}

The immunosuppressive effect of $\mathrm{NHL}$ and from its therapy provides a pathway for HBV reactivation, especially in those patients treated with anti-CD20 antibody. This effect emphasizes chronic hepatitis $B$ virus infection and reactivation as important public health issues that are preventable, especially among immunosuppressed populations. Because HBV seropositive individuals are often excluded from clinical trials of new agents, there is a paucity of data to measure the risk of morbidity and mortality from novel agent-induced HBV reactivation. Therefore, more aggressive post-market surveillance of new agents, well-designed best practice advisories, and timely case reports are needed to reduce the incidence of $\mathrm{HBV}$ reactivation. In addition, large prospective investigations coupled with well-utilized best practice advisories should be performed to understand the role of the more potent novel $\mathrm{NHL}$ therapies in HBV reactivation. Sustained HBV vaccination of children and especially adults can reduce the future risk of reactivation in patients with $\mathrm{NHL}$, but this association requires further investigation.

\section{Conflict of interest}

None

\section{Author contributions}

Conceived the topic of the review article (SD, LS), collected and reviewed pertinent articles (OOO, SD), wrote the manuscript and reviewed the final version (OOO, LS, SD), created the tables (OOO).

\section{References}

[1] Weekly epidemiological Record. Hepatitis B. vaccines. World Health Organization, 2009,p.405-420.

[2] Wasley A, Kruszon-Moran D, Kuhnert W, Simard EP, Finelli L, McQuillan G, et al. The Prevalence of hepatitis B virus infection in the United States in the era of vaccination. J Infect Dis 2010;202:192-201. doi: 10.1086/653622.

[3] Backus LI, Belperio PS, Loomis TP, Han SH, Mole LA. Screening for and prevalence of hepatitis $B$ virus infection among high-risk veterans under the care of the U.S. Department of Veterans Affairs: a case report. Ann Intern Med 2014;161:926-928. doi: 10.7326/L14-5036.

[4] Kim YM, Jeong SH, Kim JW, Lee SH, Hwang JH, Park YS, et al. Chronic hepatitis $\mathrm{B}$, non-Hodgkin's lymphoma, and effect of prophylactic antiviral therapy. J Clin Virol 2011;51:241-245. doi: 10.1016/j.jcv.2011.05.004.

[5] Kim JH, Bang Y], Park B], Yoo T, Kim CW, Kim TY, et al. Hepatitis B virus infection and B-cell non-Hodgkin's lymphoma in a hepatitis B endemic area: a case-control study. Jpn J Cancer Res 2002;93:471-477. doi: 10.1111/ j.1349-7006.2002.tb01280.x.

[6] Lim ST, Fei G, Quek R, Lim LC, Lee LH, Yap SP, et al. The relationship of hepatitis $B$ virus infection and non-Hodgkin's lymphoma and its impact on clinical characteristics and prognosis. Eur J Haematol 2007;79:132-137. doi: $10.1111 / \mathrm{j} .1600-0609.2007 .00878 . x$.
[7] Dalia S, Suleiman Y, Croy D, Sokol L. Association of lymphomagenesis and the reactivation of hepatitis $B$ virus in non-Hodgkin lymphoma. Cancer Control 2015;22:360-365.

[8] Fisher SG, Fisher RI. The epidemiology of non-Hodgkin's lymphoma. Oncogene 2004;23:6524-6534. doi: 10.1038/sj.onc.1207843.

[9] Müller AM, Ihorst G, Mertelsmann R, Engelhardt M. Epidemiology of nonHodgkin's lymphoma (NHL): trends, geographic distribution, and etiology. Ann Hematol 2005;84:1-12. doi: 10.1007/s00277-004-0939-7.

[10] Datta S, Chatterjee S, Policegoudra RS, Gogoi HK, Singh L. Hepatitis viruses and non-Hodgkin's lymphoma: A review. World J Virol 2012;1:162-173. doi: $10.5501 /$ wjv.v1.i6.162.

[11] National Cancer Institute. Non-Hodgkin lymphoma - SEER stat fact sheets. Bethesda, MD.

[12] Dong HJ, Ni LN, Sheng GF, Song HL, Xu JZ, Ling Y. Risk of hepatitis B virus (HBV) reactivation in non-Hodgkin lymphoma patients receiving rituximabchemotherapy: a meta-analysis. J Clin Virol 2013;57:209-214. doi: 10.1016/ j.jcv.2013.03.010.

[13] Evens AM, Jovanovic BD, Su YC, Raisch DW, Ganger D, Belknap SM, et al. Rituximab-associated hepatitis B virus (HBV) reactivation in lymphoproliferative diseases: meta-analysis and examination of FDA safety reports. Ann Oncol 2011;22:1170-1180. doi: 10.1093/annonc/mdq583.

[14] Fan Y, Luo C, Luo L, Huang Z, Yu H. Retrospective analysis of hepatitis B virus reactivation after rituximab combination chemotherapy in patients with B-cell lymphoma. Chinese-German Journal of Clinical Oncology 2011; 10:721-725. doi: 10.1007/s10330-011-0875-7.

[15] Koo YX, Tan DS, Tan IB, Tao M, Lim ST. Hepatitis B virus reactivation in a patient with resolved hepatitis $B$ virus infection receiving maintenance rituximab for malignant B-cell lymphoma. Ann Intern Med 2009;150:655-656. doi: 10.7326/0003-4819-150-9-200905050-00024.

[16] Lunel-Fabiani F, Masson C, Ducancelle A. Systemic diseases and biotherapies: understanding, evaluating, and preventing the risk of hepatitis $B$ reactivation. Joint Bone Spine 2014;81:478-484. doi: 10.1016/j.jbspin. 2014.01.015.

[17] Mozessohn L, Chan KK, Feld JJ, Hicks LK. Hepatitis B reactivation in HBsAgnegative/HBcAb-positive patients receiving rituximab for lymphoma: a metaanalysis. J Viral Hepat 2015;22:842-849. doi: 10.1111/jvh.12402.

[18] Ozguroglu M, Bilici A, Turna H, Serdengecti S. Reactivation of hepatitis B virus infection with cytotoxic therapy in non-Hodgkin's lymphoma. Med Oncol 2004;21:67-72. doi: 10.1385/MO:21:1:67.

[19] Yeo W, Chan PK, Chan HL, Mo FK, Johnson PJ. Hepatitis B virus reactivation during cytotoxic chemotherapy-enhanced viral replication precedes overt hepatitis. J Med Virol 2001;65:473-477. doi: 10.1002/jmv.2060.

[20] Phipps C, Chen Y, Tan D. Lymphoproliferative disease and hepatitis B reactivation: challenges in the era of rapidly evolving targeted therapy. Clin Lymphoma Myeloma Leuk 2016;16:5-11. doi: 10.1016/j.clml.2015.11.009.

[21] Yeo W, Chan HL. Hepatitis B virus reactivation associated with anti-neoplastic therapy. J Gastroenterol Hepatol 2013;28:31-37. doi: 10.1111/j.1440-1746. 2012.07280.x.

[22] Hsu C, Tsou HH, Lin SJ, Wang MC, Yao M, Hwang WL, et al. Chemotherapyinduced hepatitis $B$ reactivation in lymphoma patients with resolved HBV infection: a prospective study. Hepatology 2014;59:2092-2100. doi: 10. 1002/hep. 26718 .

[23] Ludwig E. HBV reactivation in immunosuppressed patients: prevention or containment? Hepatology 2014;59:2062-2064. doi: 10.1002/hep. 27056.

[24] Di Bisceglie AM, Lok AS, Martin P, Terrault N, Perrillo RP, Hoofnagle JH. Recent US Food and Drug Administration warnings on hepatitis $B$ reactivation with immune-suppressing and anticancer drugs: just the tip of the iceberg? Hepatology 2015;61:703-711. doi: 10.1002/hep.27609.

[25] Zhang A, Zhang M, Shen Y, Wang W, Zheng S. Hepatitis B virus reactivation is a risk factor for development of post-transplant lymphoproliferative disease after liver transplantation. Clin Transplant 2009;23:756-760. doi: 10.1111/j. 1399-0012.2009.01049.x

[26] Perrillo RP, Gish R, Falck-Ytter YT. American Gastroenterological Association Institute technical review on prevention and treatment of hepatitis $B$ virus reactivation during immunosuppressive drug therapy. Gastroenterology 2015;148:221-244.e223. doi: 10.1053/j.gastro.2014.10.038.

[27] Mastroianni CM, Lichtner M, Citton R, Del Borgo C, Rago A, Martini H, et al. Current trends in management of hepatitis $B$ virus reactivation in the biologic therapy era. World J Gastroenterol 2011;17:3881-3887. doi: 10.3748/wjg. v17.i34.3881.

[28] Hwang JP, Fisch MJ, Lok AS, Zhang H, Vierling JM, Suarez-Almazor ME. Trends in hepatitis B virus screening at the onset of chemotherapy in a large US cancer center. BMC Cancer 2013;13:534. doi: 10.1186/1471-2407-13-534.

[29] Yavuz S, Paydas S, Disel U, Sahin B. Hepatitis B virus reactivation during fludarabine therapy in non-Hodgkin's lymphoma. Leuk Lymphoma 2003; 44:1249-1250. doi: 10.1080/1042819031000079131.

[30] Lee HM, Liapakis A, Lim JK. Diagnosis, management, and prevention of hepatitis B reactivation. Curr Hepatology Rep 2015;14:184-194. doi: 10.1007/ s11901-015-0271-9. 
[31] Yeo W, Chan PK, Ho WM, Zee B, Lam KC, Lei KI, et al. Lamivudine for the prevention of hepatitis $B$ virus reactivation in hepatitis $B$ s-antigen seropositive cancer patients undergoing cytotoxic chemotherapy. J Clin Oncol 2004; 22:927-934. doi: 10.1200/JCO.2004.05.161.

[32] Lau GK, Yiu HH, Fong DY, Cheng HC, Au WY, Lai LS, et al. Early is superior to deferred preemptive lamivudine therapy for hepatitis $B$ patients undergoing chemotherapy. Gastroenterology 2003;125:1742-1749. doi: 10.1053/j. gastro.2003.09.026.

[33] Li H, Zhang HM, Chen LF, Chen YQ, Chen L, Ren H, et al. Prophylactic lamivudine to improve the outcome of $\mathrm{HBsAg}$-positive lymphoma patients during chemotherapy: a systematic review and meta-analysis. Clin Res Hepatol Gastroenterol 2015;39:80-92. doi: 10.1016/j.clinre.2014.07.010.

[34] Koo YX, Tan DS, Tan BH, Quek R, Tao M, Lim ST. Risk of hepatitis B virus reactivation in patients who are hepatitis $B$ surface antigen negative/antibody to hepatitis $\mathrm{B}$ core antigen positive and the role of routine antiviral prophylaxis. J Clin Oncol 2009;27:2570-2571; author reply 2571-2572. doi: $10.1200 / J C O .2009 .21 .9352$.

[35] Hsu C, Hsiung CA, Su IJ, Hwang WS, Wang MC, Lin SF, et al. A revisit of prophylactic lamivudine for chemotherapy-associated hepatitis $\mathrm{B}$ reactivation in non-Hodgkin's lymphoma: a randomized trial. Hepatology 2008;47: 844-853. doi: 10.1002/hep.22106.

[36] Mast EE, Weinbaum CM, Fiore AE, Alter MJ, Bell BP, Finelli L, et al. A comprehensive immunization strategy to eliminate transmission of hepatitis $B$ virus infection in the United States: recommendations of the Advisory Committee on Immunization Practices (ACIP) Part II: immunization of adults. MMWR Recomm Rep 2006;55:1-33; quiz CE1-4.

[37] Mitka M. FDA: Increased HBV reactivation risk with ofatumumab or rituximab. JAMA 2013;310:1664. doi: 10.1001/jama.2013.281115.

[38] Moreno C, Montillo M, Panayiotidis P, Dimou M, Bloor A, Dupuis J, et al. Ofatumumab in poor-prognosis chronic lymphocytic leukemia: a phase IV, non-interventional, observational study from the European Research Initiative on Chronic Lymphocytic Leukemia. Haematologica 2015;100:511-516. doi: 10.3324/haematol.2014.118158.

[39] Cameron F, McCormack PL. Obinutuzumab: first global approval. Drugs 2014;74:147-154. doi: 10.1007/s40265-013-0167-3.

[40] Kakkar AK, Balakrishnan S. Obinutuzumab for chronic lymphocytic leukemia: promise of the first treatment approved with breakthrough therapy designation. J Oncol Pharm Pract 2015;21:358-363. doi: 10.1177/1078155214534868.

[41] Ogura M, Tobinai K, Hatake K, Uchida T, Suzuki T, Kobayashi Y, et al. Phase I study of obinutuzumab (GA101) in Japanese patients with relapsed or refractory B-cell non-Hodgkin lymphoma. Cancer Sci 2013;104:105-110. doi: 10. $1111 /$ cas. 12040.

[42] Richey EA, Lyons EA, Nebeker JR, Shankaran V, McKoy JM, Luu TH, et al. Accelerated approval of cancer drugs: improved access to therapeutic breakthroughs or early release of unsafe and ineffective drugs? J Clin Oncol 2009; 27:4398-4405. doi: 10.1200/JCO.2008.21.1961.

[43] Iannitto E, Minardi V, Calvaruso G, Mulè A, Ammatuna E, Di Trapani R, et al. Hepatitis $B$ virus reactivation and alemtuzumab therapy. Eur J Haematol 2005;74:254-258. doi: 10.1111/j.1600-0609.2004.00375.x.

[44] Nakano N, Kusumoto S, Tanaka Y, Ishida T, Takeuchi S, Takatsuka Y, et al. Reactivation of hepatitis $B$ virus in a patient with adult T-cell leukemialymphoma receiving the anti-CC chemokine receptor 4 antibody mogamulizumab. Hepatol Res 2014;44:354-357. doi: 10.1111/hepr.12117.

[45] Totani $\mathrm{H}$, Kusumoto $\mathrm{S}$, Ishida $T$, Masuda A, Yoshida T, Ito A, et al. Reactivation of hepatitis $B$ virus (HBV) infection in adult T-cell leukemia-lymphoma patients with resolved HBV infection following systemic chemotherapy. Int J Hematol 2015;101:398-404. doi: 10.1007/s12185-015-1750-z.

[46] Morrison VA. Immunosuppression associated with novel chemotherapy agents and monoclonal antibodies. Clin Infect Dis 2014;59 Suppl 5:S360S364. doi: 10.1093/cid/ciu592.

[47] Grover NS, Park SI. Novel targeted agents in hodgkin and non-Hodgkin lymphoma therapy. Pharmaceuticals 2015;8:607-636. doi: 10.3390/ph8030607.

[48] Gopal AK, Kahl BS, de Vos S, Wagner-Johnston ND, Schuster S], Jurczak WJ,

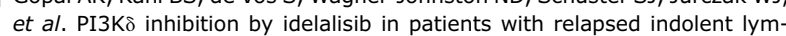
phoma. N Engl J Med 2014;370:1008-1018. doi: 10.1056/NEJMoa1314583.

[49] Flinn IW, Kahl BS, Leonard JP, Furman RR, Brown JR, Byrd JC, et al. Idelalisib, a selective inhibitor of phosphatidylinositol 3-kinase- $\delta$, as therapy for previously treated indolent non-Hodgkin lymphoma. Blood 2014;123:34063413. doi: 10.1182/blood-2013-11-538546.

[50] Cheson BD. CLL and NHL: the end of chemotherapy? Blood 2014;123:33683370. doi: 10.1182/blood-2014-04-563890.

[51] Merli M, Ferrario A, Maffioli M, Arcaini L, Passamonti F. Investigational therapies targeting lymphocyte antigens for the treatment of non-Hodgkin's lymphoma. Expert Opin Investig Drugs 2015;24:897-912. doi: 10. 1517/13543784.2015.1038342.

[52] Siddiqi T, Rosen ST. Novel biologic agents for non-Hodgkin lymphoma and chronic lymphocytic leukemia-part 2: adoptive cellular immunotherapy, small-molecule inhibitors, and immunomodulation. Oncology 2015;29: 299-308.
[53] Hwang JP, Somerfield MR, Alston-Johnson DE, Cryer DR, Feld JJ, Kramer BS, et al. Hepatitis $B$ virus screening for patients with cancer before therapy: American Society of Clinical Oncology provisional clinical opinion update. J Clin Oncol 2015;33:2212-2220. doi: 10.1200/JCO.2015.61.3745.

[54] Liu CY, Chandrasekar PH, Masood A, Schiffer CA. Adherence to hepatitis B screening and prophylactic lamivudine for prevention of rituximab-associated hepatitis B reactivation. J Oncol Pharm Pract 2013;19:18-23. doi: 10.1177/ 1078155212447975

[55] Sun WC, Hsu PI, Yu HC, Lin KH, Tsay FW, Wang HM, et al. The compliance of doctors with viral hepatitis $B$ screening and antiviral prophylaxis in cancer patients receiving cytotoxic chemotherapy using a hospital-based screening reminder system. PLoS One 2015;10:e0116978. doi: 10.1371/journal. pone. 0116978.

[56] Bréchot C, Thiers V, Kremsdorf D, Nalpas B, Pol S, Paterlini-Bréchot P. Persistent hepatitis $B$ virus infection in subjects without hepatitis $B$ surface antigen: clinically significant or purely "occult"? Hepatology 2001;34:194203. doi: 10.1053/jhep.2001.25172.

[57] National Comprehensive Cancer Network. NCCN clinical practice guidelines in oncology (NCCN guidelines ${ }^{\circledR}$ ) non-Hodgkin's lymphomas (Version 4.2014). Available at https://www.nccn.org/about/nhl.pdf.

[58] Law JK, Ho JK, Hoskins PJ, Erb SR, Steinbrecher UP, Yoshida EM. Fatal reactivation of hepatitis B post-chemotherapy for lymphoma in a hepatitis B surface antigen-negative, hepatitis B core antibody-positive patient: potential implications for future prophylaxis recommendations. Leuk Lymphoma 2005;46:1085-1089. doi: 10.1080/10428190500062932.

[59] European Association for the Study of the Liver. EASL clinical practice guidelines: management of chronic hepatitis B virus infection. J Hepatol 2012;57: 167-185. doi: 10.1016/j.jhep.2012.02.010.

[60] Liaw YF, Leung N, Kao JH, Piratvisuth $T$, Gane E, Han KH, et al. Asian-Pacific consensus statement on the management of chronic hepatitis B: a 2008 update. Hepatol Int 2008;2:263-283. doi: 10.1007/s12072-008-9080-3.

[61] Lok AS, McMahon B]. Chronic hepatitis B: update 2009. Hepatology 2009; 50:661-662. doi: 10.1002/hep.23190.

[62] Visram A, Chan KK, McGee P, Boro J, Hicks LK, Feld J]. Poor recognition of risk factors for hepatitis B by physicians prescribing immunosuppressive therapy: a call for universal rather than risk-based screening. PLoS One 2015;10:e0120749. doi: 10.1371/journal.pone.0120749.

[63] Sampedro B, Hernández-López C, Ferrandiz JR, Illaro A, Fábrega E, Cuadrado $A$, et al. Computerized physician order entry-based system to prevent HBV reactivation in patients treated with biologic agents: the PRESCRIB project. Hepatology 2014;60:106-113. doi: 10.1002/hep.27103.

[64] Dorak MT, Karpuzoglu E. Gender differences in cancer susceptibility: an inadequately addressed issue. Front Genet 2012;3:268. doi: 10.3389/fgene. 2012.00268

[65] Global routine vaccination coverage, 2014. Wkly Epidemiol Rec 2015;90: 617-623.

[66] Recommendations of the Advisory Committee on Immunization Practices (ACIP): use of vaccines and immune globulins in persons with altered immunocompetence. MMWR Recomm Rep 1993;42:1-18.

[67] Hamaki T, Kami M, Kusumi E, Ueyama J, Miyakoshi S, Morinaga S, et al. Prophylaxis of hepatitis $B$ reactivation using lamivudine in a patient receiving rituximab. Am J Hematol 2001;68:292-294. doi: 10.1002/ajh.10043.

[68] Kawai Y, Ikegaya S, Hata M, Kawahito M, Imamura S, Yoshida A, et al. Successful lamivudine therapy for post-chemotherapeutic fulminant hepatitis $B$ in a hepatitis B virus carrier with non-Hodgkin's lymphoma: case report and review of the literature. Ann Hematol 2001;80:482-484. doi: 10.1007/ s002770100322.

[69] Stroffolini T, Andriani A, Bibas M, Barlattani A. Successful treatment with lamivudine for reactivated hepatitis $B$ infection following chemotherapy for non-Hodgkin's lymphoma. Ann Hematol 2002;81:48-49. doi: 10.1007/ s00277-001-0393-8.

[70] He YF, Li YH, Wang FH, Jiang WQ, Xu RH, Sun XF, et al. The effectiveness of lamivudine in preventing hepatitis $\mathrm{B}$ viral reactivation in rituximab-containing regimen for lymphoma. Ann Hematol 2008;87:481-485. doi: 10.1007/ s00277-008-0454-3.

[71] Tonziello G, Pisaturo M, Sica A, Ferrara MG, Sagnelli C, Pasquale G, et al. Transient reactivation of occult hepatitis $B$ virus infection despite lamivudine prophylaxis in a patient treated for non-Hodgkin lymphoma. Infection 2013; 41:225-229. doi: 10.1007/s15010-012-0305-y.

[72] Chen FW, Coyle L, Jones BE, Pattullo V. Entecavir versus lamivudine for hepatitis B prophylaxis in patients with haematological disease. Liver Int 2013; 33:1203-1210. doi: 10.1111/liv.12154.

[73] Chen WC, Cheng JS, Chiang PH, Tsay FW, Chan HH, Chang HW, et al. A comparison of entecavir and lamivudine for the prophylaxis of hepatitis $B$ virus reactivation in solid tumor patients undergoing systemic cytotoxic chemotherapy. PLoS One 2015;10:e0131545. doi: 10.1371/journal.pone. 0131545 .

[74] Li HR, Huang JJ, Guo HQ, Zhang X, Xie Y, Zhu HL, et al. Comparison of entecavir and lamivudine in preventing hepatitis $B$ reactivation in lymphoma 
patients during chemotherapy. J Viral Hepat 2011;18:877-883. doi: 10. 1111/j.1365-2893.2010.01386.x.

[75] Sperl J, Frankova S, Kieslichova E, Oliverius M, Janousek L, Honsova E, et al. Urgent liver transplantation for chemotherapy-induced HBV reactivation: a suitable option in patients recently treated for malignant lymphoma. Transplant Proc 2013;45:2834-2837. doi: 10.1016/j.transproceed.2013.03.047.

[76] Huang $\mathrm{H}$, Li X, Zhu J, Ye S, Zhang H, Wang W, et al. Entecavir vs lamivudine for prevention of hepatitis $B$ virus reactivation among patients with untreated diffuse large B-cell lymphoma receiving R-CHOP chemotherapy: a randomized clinical trial. JAMA 2014;312:2521-2530. doi: 10.1001/jama.2014. 15704.

[77] Ho EY, Yau T, Rousseau F, Heathcote EJ, Lau GK. Preemptive adefovir versus lamivudine for prevention of hepatitis $B$ reactivation in chronic hepatitis $B$ patients undergoing chemotherapy. Hepatol Int 2015;9:224-230. doi: 10 . 1007/s12072-015-9612-6.

[78] Jia HY, Ding F, Chen JY, Lian JS, Zhang YM, Zeng LY, et al. Early kidney injury during long-term adefovir dipivoxil therapy for chronic hepatitis B. World J Gastroenterol 2015;21:3657-3662. doi: 10.3748/wjg.v21.i12.3657.

[79] Tanaka M, Suzuki F, Seko Y, Hara T, Kawamura Y, Sezaki H, et al. Renal dysfunction hypophosphatemia during long-term lamivudine plus adefovir dipivoxil therapy in patients with chronic hepatitis B. J Gastroenterol 2014; 49:470-480. doi: 10.1007/s00535-013-0779-0.

[80] Cheng AL, Hsiung CA, Su IJ, Chen PJ, Chang MC, Tsao CJ, et al. Steroid-free chemotherapy decreases risk of hepatitis $B$ virus (HBV) reactivation in HBVcarriers with lymphoma. Hepatology 2003;37:1320-1328. doi: 10.1053/ jhep.2003.50220.

[81] Kusumoto S, Tanaka Y, Ueda R, Mizokami M. Reactivation of hepatitis B virus following rituximab-plus-steroid combination chemotherapy. J Gastroenterol 2011;46:9-16. doi: 10.1007/s00535-010-0331-4.

[82] Ceccarelli L, Salpini R, Sarmati L, Svicher V, Bertoli A, Sordillo P, et al. Late hepatitis $B$ virus reactivation after lamivudine prophylaxis interruption in an anti-HBs-positive and anti-HBc-negative patient treated with rituximabcontaining therapy. J Infect 2012;65:180-183. doi: 10.1016/j.jinf.2011.11.021.
[83] Masarone M, De Renzo A, La Mura V, Sasso FC, Romano M, Signoriello G, et al. Management of the $\mathrm{HBV}$ reactivation in isolated $\mathrm{HBCAb}$ positive patients affected with Non Hodgkin Lymphoma. BMC Gastroenterol 2014;14:31. doi: 10.1186/1471-230X-14-31.

[84] Picardi M, Pane F, Quintarelli C, De Renzo A, Del Giudice A, De Divitiis B, et al. Hepatitis $B$ virus reactivation after fludarabine-based regimens for indolent non-Hodgkin's lymphomas: high prevalence of acquired viral genomic mutations. Haematologica 2003;88:1296-1303.

[85] Win LL, Powis J, Shah H, Feld JJ, Wong DK. Death from liver failure despite lamivudine prophylaxis during R-CHOP chemotherapy due to rapid emergence M204 mutations. Case Reports Hepatol 2013;2013:454897. doi: 10. $1155 / 2013 / 454897$.

[86] Kim IK, Kim BG, Kim W, Kim D, Kim YJ, Yoon JH, et al. Clinical prediction of failure of lamivudine prophylaxis for hepatitis B virus-infected patients undergoing cytotoxic chemotherapy for malignancy. Antimicrob Agents Chemother 2012;56:5511-5519. doi: 10.1128/AAC.00821-12.

[87] Benten D, Sterneck M, Panse J, Rogiers X, Lohse AW. Low recurrence of preexisting extrahepatic malignancies after liver transplantation. Liver Transpl 2008;14:789-798. doi: 10.1002/lt.21434.

[88] Carosi G, Rizzetto M, Alberti A, Cariti G, Colombo M, Craxì A, et al. Treatment of chronic hepatitis B: update of the recommendations from the 2007 Italian Workshop. Dig Liver Dis 2011;43:259-265. doi: 10.1016/j.dld.2010.10.014.

[89] Lok AS, McMahon BJ, Brown RS Jr, Wong JB, Ahmed AT, Farah W, et al. Antiviral therapy for chronic hepatitis B viral infection in adults: A systematic review and meta-analysis. Hepatology 2016;63:284-306. doi: 10.1002/ hep. 28280.

[90] Sorrell MF, Belongia EA, Costa J, Gareen IF, Grem JL, Inadomi JM, et al. National Institutes of Health Consensus Development Conference Statement: management of hepatitis B. Ann Intern Med 2009;150:104-110. doi: 10.7326/0003-4819-150-2-200901200-00100.

[91] Liu WC, Phiet $\mathrm{PH}$, Chiang TY, Sun KT, Hung KH, Young KC, et al. Five subgenotypes of hepatitis $\mathrm{B}$ virus genotype $\mathrm{B}$ with distinct geographic and virological characteristics. Virus Res 2007;129:212-223. doi: 10.1016/j. virusres.2007.07.016. 